\title{
HVORDAN FOREBYGGE TRYKKSÅR?
}

En viktig del av omsorgen for pasienter i sykehus og sykehjem er å forebygge trykksår.

\section{/ IIhelsebiblioteket.no}

\author{
Av Anne Bergland, seniorrådgiver
}

Bevissthet rundt problemet og tilgang til kvalitetssikret informasjon kan bidra til å spare pasienten for mye smerte og redusert livskvalitet, samtidig som det vil spare helsetjenesten for betydelige kostnader.

Du har en pasient som du vet er i risikogruppen for å utvikle trykksår. Det er en stund siden du har stått overfor denne problemstillingen og du trenger oppdatering. Er du usikker på hvordan du skal gå fram for å finne kvalitetssikret informasjon om forebygging av trykksår? Her er noen tips til hvordan du effektivt kan finne god kunnskap.

$\AA$ jobbe kunnskapsbasert vil si at man som helsepersonell tar faglige avgjørelser basert på den til enhver tid beste tilgjengelige forskningsbaserte kunnskap, erfaringsbasert kunnskap og pasientens behov og ønsker (1).

På Helsebiblioteket.no får du tilgang til flere ulike kilder som kan hjelpe deg å jobbe kunnskapsbasert. Disse kildene befinner seg på ulike nivåer i den såkalte Kunnskapspyramiden, utviklet av Brian Haynes (2). Pyramiden er laget slik at hvert nivå bygger på innholdet i nivået under. Øverst ligger kunnskapsbaserte oppslagsverk, prosedyrer og retningslinjer, deretter kvalitetsvurderte systematiske oversikter og nederst ligger primærstudiene. Det anbefales at du begynner å lete etter svar så høyt opp i pyramiden som mulig.

\section{OPPSLAGSVERK OG RETNINGSLINJER}

På øverste nivå i pyramiden ligger fremtidens pasientjournalsystemer der verktøy for klinisk beslutningsst $\varnothing$ tte er integrert med data fra pasientjournalene. Vi er ikke helt der ennå, så derfor må du begynne på nivået under, med kliniske oppslagsverk og retningslinjer.

Nasjonalt nettverk for fagprosedyrer er et samarbeidsprosjekt om prosedyrer innen spesialisthelsetjenesten. Prosjektet koordineres av Nasjonalt kunnskapssenter for helsetjenesten. Alle helseforetak er velkomne til å delta i samarbeidet.

Det er lett å finne frem på nettverkets sider www. fagprosedyrer.no. Under menypunktet Fagprosedyrer kan du velge å hente fram prosedyrer alfabetisk eller etter emne. Under «Hud» ligger «Trykksår forbygging» (3).

I denne prosedyren finner du viktige prinsipper i forebyggingen. Her er noen eksempler:

- Huden til pasienter i risikogruppen skal daglig undersøkes for tegn på rødhet. Det kan være nødvendig å gjenta dette oftere ved forverring av pasientens tilstand.

- Hudområder som er i risiko for å utvikle trykksår skal ikke masseres.

- Risikopasienters ernæringsstatus skal kartlegges og vurderes ved innleggelse og fortløpende under oppholdet.

- Behovet for trykkfordelende underlag og stillingsforandring vurderes regelmessig. (3)

Prosedyren inneholder også to flytskjema om risikovurdering og forebygging av trykksår. Det ene omhandler risikogruppen generelt, og det andre går spesifikt på operasjonspasienten. Fagprosedyren er laget av Oslo universitetssykehus, men kan fritt lastes ned, tilpasses lokale forhold og godkjennes for bruk i andre helseforetak.

Helsebiblioteket har en egen retningslinjeda- 


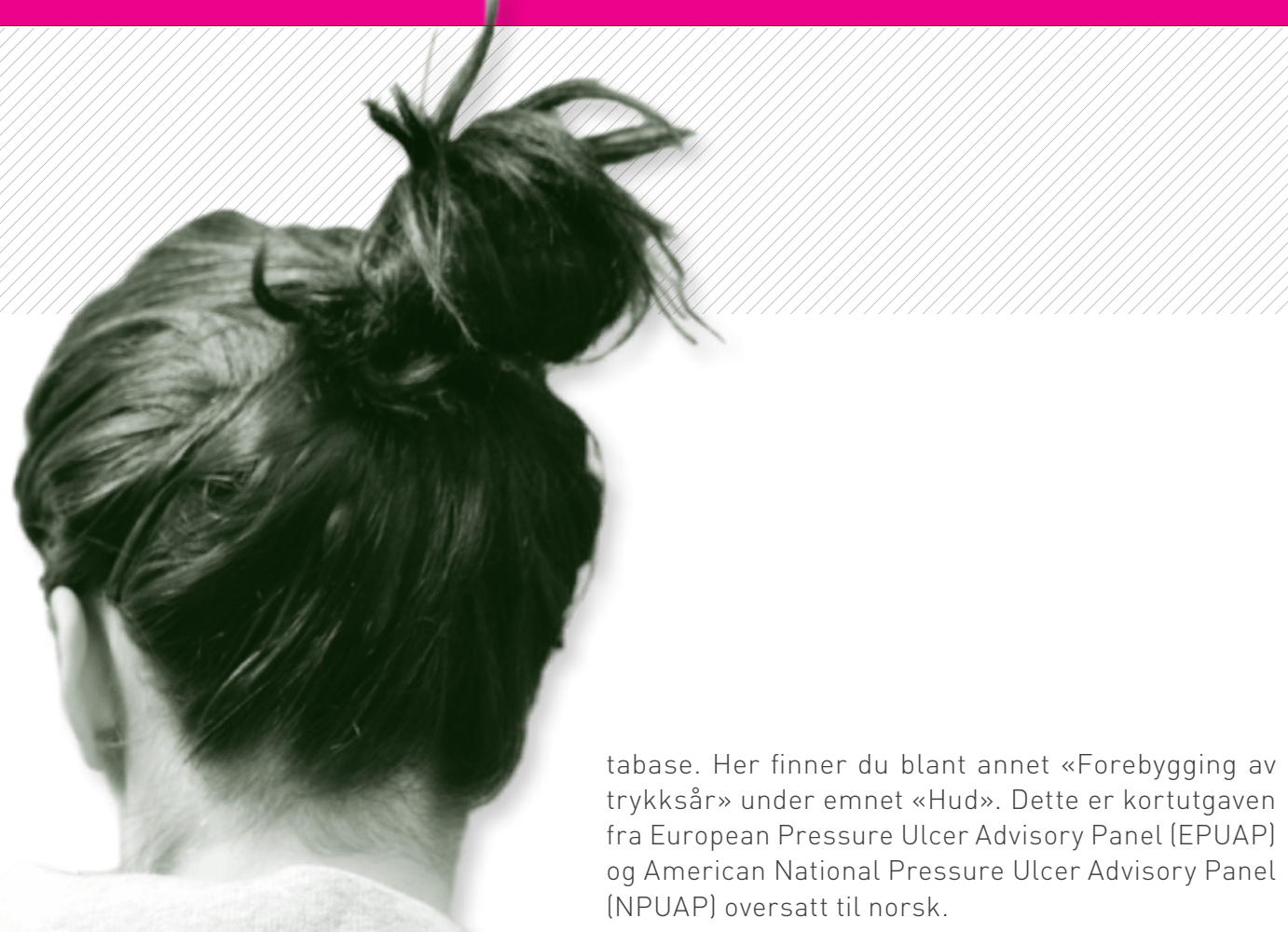

tabase. Her finner du blant annet «Forebygging av trykksår» under emnet «Hud». Dette er kortutgaven fra European Pressure Ulcer Advisory Panel (EPUAP) (NPUAP) oversatt til norsk.

\section{BEHANDLINGSANBEFALINGER}

Oppslagsverkene BMJ Best Practice og UpToDate presenterer behandlingsanbefalinger basert på resultater av store mengder forskning. Et søk på ordet
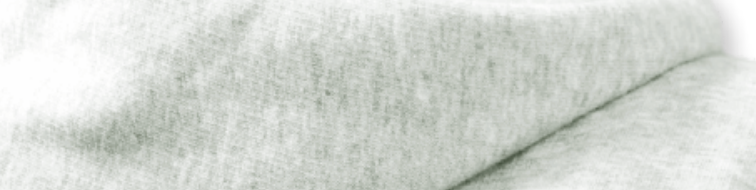
«pressure ulcer» i BMJ Best Practice fører deg til en side om trykksår, med egen fane om blant annet forebygging. I UpToDate kommer «pressure ulcer prevention» opp som et alternativ når du skriver «pressure ulcer» i søkefeltet.

Gjennom trinnene vist over har du funnet praktiske prosedyrer og anbefalinger som du kan bruke i pasientmøtet. I forhold til det å jobbe kunnskapsbasert ville det vært greit å stoppe jakten på svar her. Det kan imidlertid ta litt tid før resultater fra forskning tas inn i kildene øverst i pyramiden, så i andre tilfeller kan det i tillegg være lurt å se etter gode systematiske oversikter. Det samme gjelder ved behov for fordypning.

\section{VIDERE SøKING}

Lengre ned i pyramiden finner du systematiske oversikter, sekundærtidsskrifter og primærstudier. Eksempler på kilder som inneholder denne typen publikasjoner er:

- Cochrane Library - inneholder systematiske oversikter over ulike forebyggende tiltak og behandlinger.

- Evidence Based Nursing og Joanna Briggs sekundærtidsskrifter med sykepleie som fagområde.

- British Nursing Index - en sykepleiefaglig database med artikler innen sykepleie og jordmorfag.

- MEDLINE - verdens største medisinske database. Her finner du også mange sykepleiefaglige artikler.

Noen av disse databasene er selvforklarende og enkle å bruke, mens andre krever litt veiledning eller trening. Bibliotekarer er eksperter i å finne fram i slike kilder, og dersom du har tilgang til et fagbibliotek der du jobber, kan det være lurt å be om hjelp der. Du kan også finne veiledninger under «Hjelp» på Helsebiblioteket.no.

Husk at kvaliteten på primærstudiene kan variere og at det er viktig med et kritisk blikk når man befinner seg på de nederste nivåene i pyramiden. Nasjonalt kunnskapssenter for helsetjenesten har laget selvforklarende, enkle sjekklister til bruk ved kritisk vurdering av primærstudier (4).

\section{PASIENTINFORMASJON}

Trenger du pasientinformasjon som du kan skrive ut til pasienten? Det finner du også på Helsebiblioteket.no, under fanen «Pasientinformasjon». Brosjyrer fra BMJ Best Practice er oversatt til norsk og noe tilrettelagt norske forhold og kvalitetssikret av norsk helsepersonell. Under «T» finner du brosjyren «Trykksår» (5), som foruten å forklare hva trykksår er, tar for seg symptomer, forbygging, behandling og prognose. Brosjyrens oppbygging og språk er tilpasset målgruppens forutsetninger og behov.

\section{REFERANSER}

1. www.kunnskapsbasertpraksisk.no

2. DiCenso A, Bayley L, Haynes RB. Accessing preappraised evidence: fine-tuning the $5 \mathrm{~S}$ model into a $6 \mathrm{~S}$ model. (PDF) Ann Intern Med, 2009: 115: JC3-2.

3.http://www.helsebiblioteket.no/microsite/Fagprosedyrer/ Fagprosedyrer/Trykks\%C3\%A5r+\%E2 \%80\%93+forebygging. 99338. cms

4.http://www.kunnskapssenteret.no/Verkt\%C3 \%B8y/Sjekkli ster+for+vurdering+av+forskningsartikler. 2031. cms

5.http://www.helsebiblioteket.no/Pasientinformasjon/Brosjyrer/Trykks\%C3 \%A5r. 72307. cms 